\title{
Fluorescent antibody responses to adenoviruses in humans
}

\author{
J. P. ARIYAWANSA 1 AND J. O'H. TOBIN ${ }^{2}$ \\ From the Public Health Laboratory, Withington Hospital, Manchester M20 8LR
}

SYNOPSIS Specific IgG, IgA, and IgM immunoglobulin antibody responses to adenovirus infections were studied by the indirect immunofluorescent technique in six pairs of human sera obtained during acute and convalescent phases of the illness. In addition, 70 single specimens of sera showing adenovirus IgG antibody from different age groups from birth to the 60th year of life were titrated for the same antibody to adenovirus types $1,2,3,5$, and 7, and 170 serum specimens from the same age groups were screened for specific immunoglobulin antibodies against types 1 and 5 .

Specific immunoglobulin antibodies lacked type specificity and in acute infections measured heterologous antibody response as well. On the other hand, IgG antibodies detected in single specimens of sera by immunofluorescence correlate with surveys of the isolation of virus from patients and neutralizing antibody studies by other workers.

Fluorescent antibodies appeared in all three fractions of the immunoglobulins in acute adenovirus infections. Although this technique may be used in the diagnosis of adenovirus infections there is no advantage compared to complement-fixation testing. However, the use of sera absorbed with group antigen may have a more useful place in serological epidemiology than in diagnostic work.

In five pairs of sera obtained during acute and convalescent phases of adenoviral illness and in 70 random single specimens from different age groups, ' $T$ ' antibodies were detected only in the IgG fraction. The paired sera did not show a significant rise to indicate the usefulness of ' $T$ ' antibody study in diagnosis.

Serodiagnosis of adenovirus infections is usually made by the complement-fixation (CF) test. Although this is the most convenient assay procedure available, this test detects fewer than $50 \%$ of infections owing to the constant high level of antibodies in many individuals (Ginsberg, 1972). Haemagglutination inhibition (HI) and neutralizing antibody techniques are not generally employed in routine diagnosis. Thus it seemed worth while applying the indirect immunofluorescent method to the diagnosis of adenovirus infections and to random sera from different age groups.

With the discovery of the oncogenicity of adenovirus types 12 and 18 for newborn hamsters and rats (Huebner et al, 1962; Trentin et al, 1962) ' $T$ ' antigens have been produced in tissue culture systems by artificially inhibiting viral replication with cytosine arabinoside (Feldman and Rapp, 1966). It

\footnotetext{
1Present address: Medical Research Institute, Colombo 8, Sri Lanka 'Present address: Public Health Laboratory, Radcliffe Infirmary, Oxford

Received for publication 14 October 1975
}

has been possible to classify the human types into four subgroups $A, B, C$, and $D$ on ' $T$ ' antigen reactivity (Gilden et al, 1970). There is a certain degree of similarity of this subgrouping to the subgrouping suggested by Rosen (1960) on the basis of haemagglutination with rhesus monkey and rat erythrocytes. The subgroups A, B, C, and D correspond to subgroups $4,1,3$, and 2 , respectively, of Rosen's classification. However, types 4, 20, 25, and 28 occupy dissimilar positions in the haemagglutination subgroup. Attempts have been made to study the ' $T$ ' antibody response in acute adenovirus infections, the character of these responses, and their relationship to the ' $T$ ' antigen subgroups, and to evaluate the pattern at different ages.

\section{Material and Methods}

\section{VIRUSES}

Adenovirus types 1, 2, 3, 5, and 7 were isolated from clinical material in rhesus monkey kidney tissue culture and typed by the neutralization test. The 
original specimens were received at the Public Health Laboratory (PHL), Withington Hospital, Manchester. Types 4 and 12 were obtained from Dr M. S. Pereira, Central Public Health Laboratory, Colindale Avenue, London NW9 5HT.

\section{SERA}

Sera were received for diagnostic viral serology at the PHL, Withington Hospital, Manchester, stored at $-20^{\circ} \mathrm{C}$, and inactivated at $56^{\circ} \mathrm{C}$ for 30 minutes at 1:5 dilution with barbitone buffer before use.

\section{CELL CULTURES AND MEDIA}

1 Rhesus monkey kidney (RMK), supplied by the Microbiological Research Establishment, Porton, was grown in medium 199 with $10 \%$ calf serum, and for maintenance $2 \%$ embryo calf serum was used.

2 MRC 5 cells from the Medical Research Council Laboratory, Hampstead, London were grown and maintained in Eagle's basal medium with $10 \%$ and $7 \%$ calf serum respectively.

\section{REAGENTS}

1 Phosphate buffered saline A (PBSA) pH 7.2

2 Buffered glycerol pH 9.0: equal volumes of Analar glycerol and carbonate-bicarbonate buffer $(\mathrm{pH}$ $9 \cdot 0,0 \cdot 5 \mathrm{M}$ )

3 Brilliant cresyl blue, 1:10000 solution in PBSA

4 Cytosine arabinoside (Cytarabine) supplied by Upjohn Ltd, Fleming Way, Crawley, Sussex

5 Anti-IgG conjugate was obtained from Wellcome Reagents Ltd and used at 1:50 dilution. Anti-IgA and IgM conjugates (Nordic Pharmaceuticals) at $1: 5$ dilution in PBSA were absorbed with uninfected MRC 5, RMK, and HeLa cells at $4^{\circ} \mathrm{C}$ for 24 hours with each cell type. IgA conjugate was used at 1:70 and IgM at 1:40. Optimum working dilutions of the conjugates were obtained by testing serial dilutions of the conjugate with the relevant lowest dilution of a standard positive serum.

6 The latex slide test (Wellcome Laboratories Ltd) was used for the detection of anti-IgG immunoglobulins. The serum dilution used for the test was $1: 5$.

VIRUS INFECTED CELLS ON PTFE COATED SLIDES

Polytetrafluroethylene (PTFE) coated multispot slides (C. A. Hendley \& Co, Victoria Road, Essex) were used to prepare cell discs (De Silva et al, 1973). $0.05 \mathrm{ml}$ of MRC 5 cell suspension containing 75000 cells per $\mathrm{ml}$ in growth medium (GM) was applied to each of the spots. Slides were placed in a plastic square Petri dish and incubated in a carbon dioxide atmosphere of about $5 \%$ ('candle box') at $37^{\circ} \mathrm{C}$ for 24 hours, after which the growth medium was replaced with $0.05 \mathrm{ml}$ of virus suspension made in maintenance medium (MM) at a predetermined $\stackrel{5}{+}$ working dilution of the virus stored in liquid? nitrogen. Incubation continued as before at $35^{\circ} \mathrm{C}$ 흘 for 24 hours when each Petri dish was flooded with $\frac{\bar{\omega}}{\overrightarrow{0}}$ $20 \mathrm{ml}$ of $\mathrm{MM}$ and incubation was continued at $\stackrel{\otimes}{\stackrel{\Phi}{\Omega}}$ $35^{\circ} \mathrm{C}$ as before.

Forty-eight hours after the initial incubation of cells, a slide was harvested by being rinsed in two. separate baths of PBSA and two separate baths of $\vec{\omega}$ acetone, and fixation in a third acetone bath for $\stackrel{\circ}{\circ}$ 2 minutes before being dried. All the slides were $\frac{?}{8}$ harvested when each cell disc showed 30-40 well î distributed fluorescent cells after staining with the of conjugate (described below). A stock of slides thus $A$ prepared was stored at $-40^{\circ} \mathrm{C}$ in plastic slide $\vec{A}$ containers.

\section{PREPARATION OF ADENOVIRUS ' $T$ ' ANTIGEN}

Adenovirus types used were $1,3,4$, and 12 , represen- $\vec{\varphi}$ ting subgroups $\mathrm{C}, \mathrm{B}, \mathrm{D}$, and $\mathrm{A}$ respectively. The above procedure was followed with the following modifications. After the inoculation of cell discs with virus, and incubation (in a candle box) at $37^{\circ} \mathrm{C}$ for 2 hours, $0.05 \mathrm{ml}$ of $\mathrm{MM}$ with $10 \mu \mathrm{g}$ of cytosine arabinoside per $\mathrm{ml}$ was added to the virus suspension $\frac{\varnothing}{\Phi}$ in each of the cell discs. The slides were then in- $\frac{\varrho}{a}$ cubated for a further 24 hours at $35^{\circ} \mathrm{C}$ and each $\overline{0}$ Petri dish was flooded with $20 \mathrm{ml}$ of MM containing $5 \mu \mathrm{g}$ of cytosine arabinoside per ml. Incubation was continued as before. Slides inoculated with virus and without cytosine arabinoside served as controls. Forty-eight hours after the initial infection the first harvesting was done from the control and cytosine 3 . treated preparations as described before. The $\dot{\delta}$ remaining slides were harvested when stippling nuclear fluorescence appeared in cytosine treated $\mathrm{O}$ cells after immunofluorescent staining.

INDIRECT IMMUNOFLUORESCENT ANTIBODY TECHNIQUE (IFAT)

The infected cell discs were separated from each $N$ other with an instant drying waterproof black ink N్ marker (Artline 70) and stained with $0.025 \mathrm{ml}$ of $\sigma$ inactivated patients' sera for 30 minutes in a moist chamber at $37^{\circ} \mathrm{C}$. The serum was washed off with $\frac{\mathrm{C}}{\mathrm{D}}$ PBSA in two separate baths with a magnetic stirrer $\stackrel{\oplus}{+}$ for 5-10 minutes each. The slides were dried, stained 7 with $0.025 \mathrm{ml}$ of the appropriate antihuman globulin conjugate, and left in the incubator at $37^{\circ} \mathrm{C}$ in a moist chamber for 30 minutes. The conjugate was washed off with PBSA as previously described and $\frac{\Omega}{\sigma}$ stained in $0.01 \%$ brilliant cresyl blue for $8-10$ 
seconds, and excess stain was removed by rinsing in PBSA. Coverslips were mounted with buffered glycerol (pH 9.0) and the slides were examined by fluorescent microscopy (Laboratory Conference Microscope by Gillert \& Sibert, Lynx House, London SW1) with glycerol on the substage, using a wide angle dark ground condenser, a 12 volt 100 watt halogen quartz lamp, a Turner fluorescein primary filter, and a $\times \mathbf{4 0}$ objective.

The titration of positive sera was carried out using three-fold dilutions and a cell disc per dilution. The process of staining with all three globulin conjugates was the same.

\section{Results}

\section{PAIRED SERA}

Six pairs of sera showing adenovirus CF antibody rises were titrated for $\operatorname{IgG}, \operatorname{IgA}$, and $\operatorname{IgM}$ antibody to types 1 and 5 (table I). No virus isolations were made except from case 6 which yielded adenovirus type 7 . The responses observed showed rises in all immunoglobulin fractions to both viruses tested. The relationship of immunofluorescent antibody levels to CF levels was variable. Case 1 had fluorescent IgG antibody titres of 15 and 12.15 against type 1 , when the CF titres were less than 10 and 320 , while in others, eg, case 5, IgG titres were less than CF titres. The difference in IgG antibody titres against types 1 and 5 in the acute and convalescent specimens or both (as in cases 1, 2, and 5) was only threefold. Thus no significant difference in type response was found. This was further confirmed in case 6 against adenovirus type 7 .

\section{DIFFERENT AGES}

To study the pattern of distribution of fluorescent antibodies by age, seven age groups were selected: under 6 months, 6-11 months, 1-4 years, 5-10 years, 11-20 years, 21-35 years, and 36-60 years. The estimation of IgG antibodies in 10 of the IgG positive sera in each of these age groups was made against adenovirus types $1,2,3,5$, and 7 . The geometric mean titres of each age group are represented graphically against the respective types in figure 1. High geometric mean titres for IgG antibodies against types 1,2 , and 5 were seen in all age groups, types 3 and 7 showing responses in late childhood and adult life.

Thirty sera from each of the age groups up to 4 years and 20 sera from the remaining age groups were screened at 1:5 dilution for $\mathrm{IgG}, \mathrm{IgA}$, and IgM antibodies against types 1 and 5. Figures 2 and 3 show the distribution of percentage positives in the respective age groups. In both graphs more positive IgG sera are seen in infants under 6 months than in the next older group, and a gradual rise is observed thereafter. IgA antibody generally parallels IgG antibody but at a lower incidence and shows a similar pattern with both viruses tested. The IgM antibody patterns are different against the two viruses.

The paired sera gave negative results for rheumatoid factor by the latex flocculation method, thus probably ruling out false positive IgM activity (Fraser et al, 1971).

\section{T ANTIBODIES}

In five pairs of sera showing $\mathrm{CF}$ antibody rise ' $\mathrm{T}$ ' antibody was found only in the IgG portion of immunoglobulins (table II) as in single sera of age groups. One serum pair failed to give a fluorescent reaction with all four virus types at the dilution $(1: 5)$ used. The titres obtained for $\mathrm{JgG}$ ' $T$ ' antibodies were comparatively low when compared with fluorescent IgG titres against full cycle viral antigens.

\begin{tabular}{|c|c|c|c|c|c|c|c|c|c|c|}
\hline \multirow[t]{2}{*}{ Case } & \multicolumn{3}{|c|}{ Type 1} & \multicolumn{3}{|c|}{ Type 5} & \multirow[t]{2}{*}{$C F T$} & \multirow{2}{*}{$\begin{array}{l}\text { Age } \\
(y r)\end{array}$} & \multirow[t]{2}{*}{ Sex } & \multirow{2}{*}{$\begin{array}{l}\text { Interval between } \\
\text { Onset and Sera } \\
\text { (days) }\end{array}$} \\
\hline & $I g G$ & $\operatorname{Ig} A$ & $I g M$ & $\lg G$ & $\operatorname{Ig} A$ & $I g M$ & & & & \\
\hline 1 & $\begin{array}{r}15 \\
1215\end{array}$ & $\begin{array}{r}15 \\
405\end{array}$ & $\begin{array}{l}<5 \\
405\end{array}$ & $\begin{array}{r}15 \\
405\end{array}$ & $\begin{array}{r}5 \\
405\end{array}$ & $\begin{array}{l}<5 \\
405\end{array}$ & $<\underset{320}{10}$ & 56 & $\mathbf{F}$ & $\begin{array}{r}5 \\
12\end{array}$ \\
\hline 2 & $\begin{array}{r}45 \\
405\end{array}$ & $\begin{array}{r}15 \\
135\end{array}$ & $\begin{array}{r}5 \\
135\end{array}$ & $\begin{array}{r}15 \\
135\end{array}$ & $\begin{array}{r}15 \\
135\end{array}$ & $\begin{array}{r}5 \\
45\end{array}$ & $<\begin{array}{r}10 \\
160\end{array}$ & 7 & $\mathbf{M}$ & $\begin{array}{r}2 \\
10\end{array}$ \\
\hline 3 & $\begin{array}{r}45 \\
405\end{array}$ & $\begin{array}{r}45 \\
405\end{array}$ & $\begin{array}{r}45 \\
405\end{array}$ & $\begin{array}{r}45 \\
405\end{array}$ & $\begin{array}{r}45 \\
405\end{array}$ & $\begin{array}{l}135 \\
405\end{array}$ & $\begin{array}{r}160 \\
>320\end{array}$ & - & $\mathbf{M}$ & $\begin{array}{r}2 \\
11\end{array}$ \\
\hline 4 & $\begin{array}{l}15 \\
45\end{array}$ & $\begin{array}{r}15 \\
135\end{array}$ & $\begin{array}{r}5 \\
45\end{array}$ & $\begin{array}{l}15 \\
45\end{array}$ & $\begin{array}{l}15 \\
45\end{array}$ & $\begin{array}{l}15 \\
45\end{array}$ & $<\begin{array}{r}10 \\
20\end{array}$ & 39 & $\mathbf{M}$ & $\begin{array}{r}2 \\
13\end{array}$ \\
\hline 5 & $<\begin{array}{r}5 \\
15\end{array}$ & $\begin{array}{l}<5 \\
15\end{array}$ & $\begin{array}{r}5 \\
15\end{array}$ & $\begin{array}{r}<5 \\
5\end{array}$ & $\begin{array}{l}<5 \\
45\end{array}$ & $\begin{array}{r}5 \\
45\end{array}$ & $\begin{array}{l}10 \\
80\end{array}$ & 2 & $\mathbf{F}$ & $\begin{array}{r}2 \\
15\end{array}$ \\
\hline 6 & $\begin{array}{r}15 \\
405\end{array}$ & $\begin{array}{r}15 \\
135\end{array}$ & $\begin{array}{r}15 \\
405\end{array}$ & $\begin{array}{r}15 \\
405\end{array}$ & $\begin{array}{r}15 \\
135\end{array}$ & $\begin{array}{r}15 \\
405\end{array}$ & $\begin{array}{r}10 \\
160\end{array}$ & 3 & $\mathbf{M}$ & 3 \\
\hline
\end{tabular}

Table I Titres ${ }^{1}$ of $\operatorname{IgG}, \operatorname{Ig} A$, and IgM in serum pairs against adenovirus types 1 and 5

Type 7 was isolated from case 6. The values of IgA and IgM against type 7 were the same as with types 1 and 5, except a titre of 45 for IgG with acute serum.

- not known

${ }^{1}$ reciprocal of dilution end point 

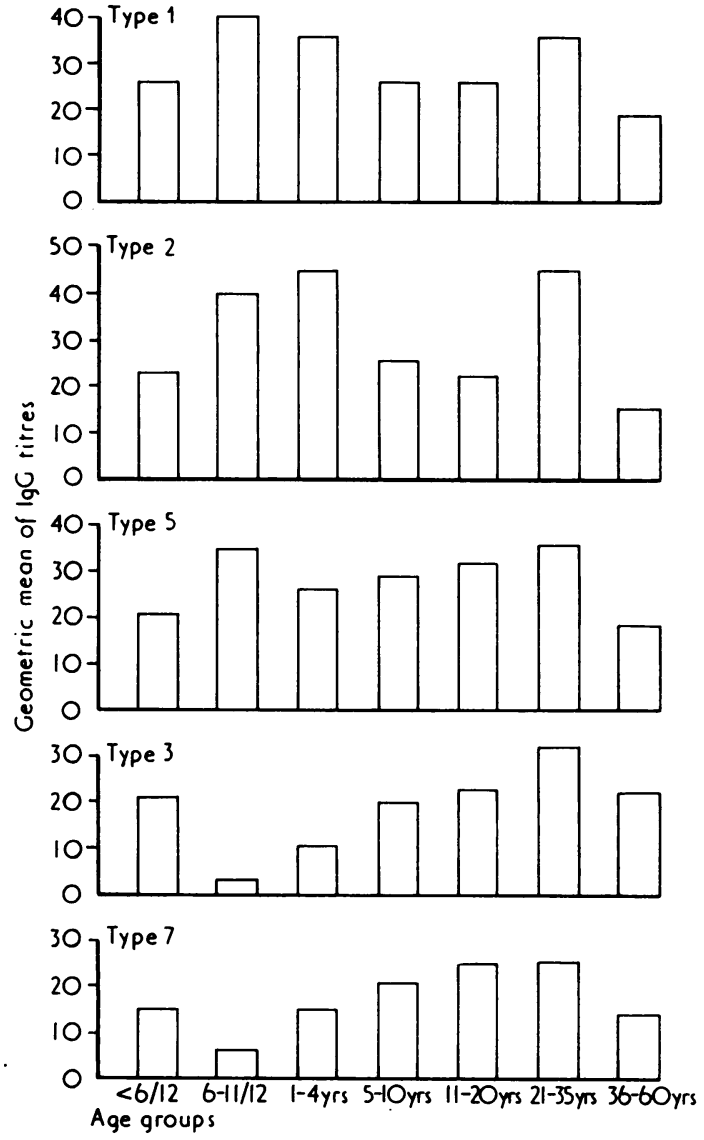

Fig 1 Age distribution of IgG antibody against adenovirus types $1,2,5,3$, and 7

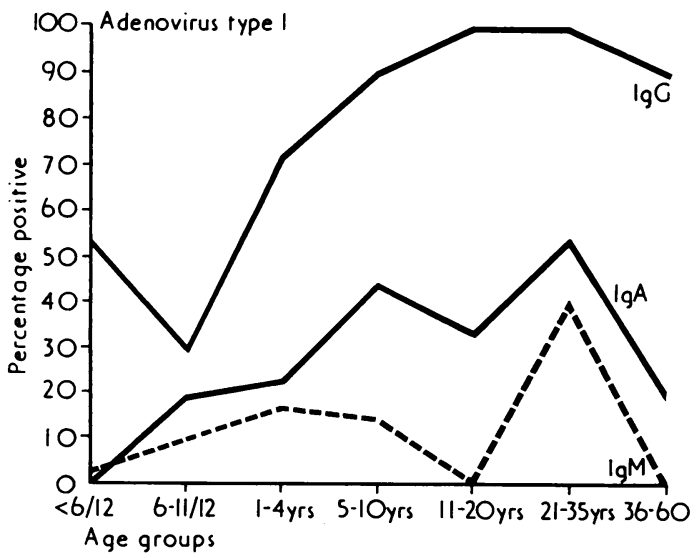

Fig 2 Prevalence of $\operatorname{IgG}, \operatorname{Ig} A$, and $\operatorname{Ig} M$ antibodies to adenovirus type 1 in age group sera

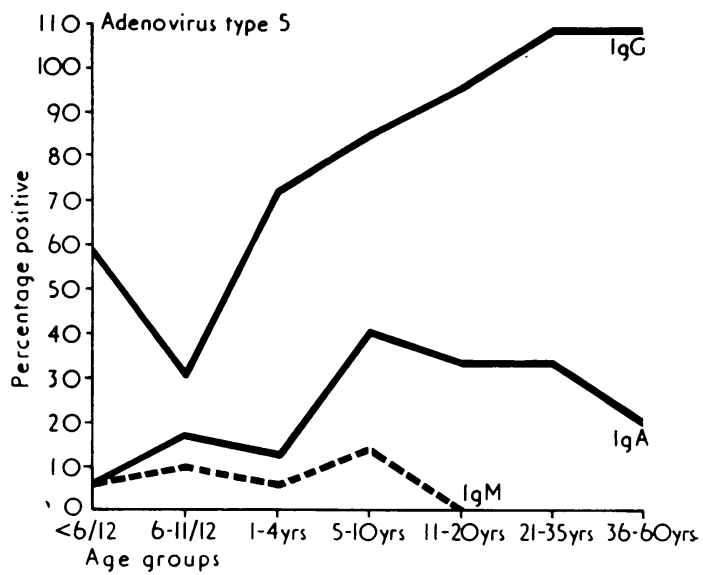

Fig 3 Prevalence of $\operatorname{Ig} G, \operatorname{Ig} A$, and $\operatorname{Ig} M$ antibodies to adenovirus type 5 in age group sera

The geometric mean titre to ' $T$ ' antibodies against adenovirus type 1 was 5 in both first and second $\stackrel{\varphi}{\theta}$ sera (range $<5$ to 45 ); whereas the geometric mean titres for IgG antibodies against full cycle viral antigens against the same type was 15 (range $<5$ to 45) and 135 (range 15 to 1215) respectively. All four types of viruses employed in the test detected the presence of ' $T$ ' antibodies with minor differences in $\stackrel{\triangle}{\triangle}$ their titres as shown by cases 1 and 2 , indicating $\overrightarrow{\vec{O}}$ lack of subgroup specificity.

Ten sera from each of the above age groups when screened for ' $T$ ' antibodies against ' $T$ ' antigens of adenovirus types $1,3,4$, and 12 of the four subgroups revealed its presence only in the IgG fraction. The results are shown in figure 4. A rise is observed in 3 young adults to all except type 4, while in the older age group a falling incidence is observed against all types.

\section{Discussion}

Specific adenovirus $\operatorname{IgG}, \operatorname{IgA}$, and $\operatorname{IgM}$ antibodies $\widetilde{N}$ were detected by immunofluorescence in sera from cases. The antibodies detected were not specific for the infecting virus type but were group specific, $\omega$ similar to the specific immunoglobulin antibodies detected by radio-immunodiffusion (Bellantiet al, 1969). In one case tested 10 months after the acute illness, $\underset{\mathscr{D}}{\stackrel{D}{ }}$ IgM, IgA and IgG antibodies were still detected,, indicating that the presence of IgM antibody does not necessarily indicate a very recent infection with $\overrightarrow{\mathbb{D}}$ adenoviruses, whereas this seems to be the case with $\stackrel{?}{\longrightarrow}$ rubella and influenza when IgM antibody is measured $\stackrel{\mathbb{Q}}{\square}$ by a similar immunofluorescent method (CradockWatson et al, 1972; Urquhart, 1974). More recent 8 


\begin{tabular}{|c|c|c|c|c|c|c|c|c|c|c|c|c|c|}
\hline \multirow[t]{3}{*}{ Case } & \multirow[t]{3}{*}{$C F T$} & \multicolumn{12}{|c|}{ Adenovirus } \\
\hline & & \multicolumn{3}{|c|}{ Type $1^{1}$} & \multicolumn{3}{|c|}{ Type 3} & \multicolumn{3}{|c|}{ Type 4} & \multicolumn{3}{|c|}{ Type 12} \\
\hline & & $I g G$ & $\operatorname{Ig} A$ & $I g M$ & $I g G$ & $\operatorname{Ig} A$ & $\operatorname{Ig} M$ & $\operatorname{Ig} G$ & $\operatorname{Ig} A$ & IgM & $I g G$ & $\operatorname{Ig} A$ & $\operatorname{Ig} M$ \\
\hline \multirow[t]{3}{*}{1} & $<10$ & - & - & - & - & - & - & - & - & - & - & - & - \\
\hline & 320 & 45 & - & - & 15 & - & - & 45 & - & - & 15 & - & - \\
\hline & $<10$ & 5 & - & - & - & - & - & 5 & - & - & 5 & - & - \\
\hline \multirow{2}{*}{2} & 160 & 15 & - & - & 15 & -- & - & 15 & - & - & 5 & - & - \\
\hline & $<10$ & - & - & - & 5 & - & - & - & - & - & 5 & - & - \\
\hline \multirow{2}{*}{3} & 20 & - & - & - & 5 & - & - & 5 & - & - & 5 & - & - \\
\hline & 10 & - & - & - & - & - & - & - & - & - & - & - & - \\
\hline \multirow{2}{*}{4} & $\begin{array}{l}80 \\
10\end{array}$ & $\overline{15}$ & $\bar{z}$ & $\bar{z}$ & 二 & $=$ & 二 & $=$ & 二 & $\bar{z}$ & Z & E & 二 \\
\hline & 160 & 15 & - & - & 5 & - & - & - & - & - & 5 & - & - \\
\hline
\end{tabular}

Table II Estimation of ' $T$ ' antibodies in paired sera

- not present at $1 / 5$ dilution

${ }^{1}$ types $1,3,4$, and 12 belong to ' $T$ ' antigen subgroups $C, B, D$, and $A$ respectively

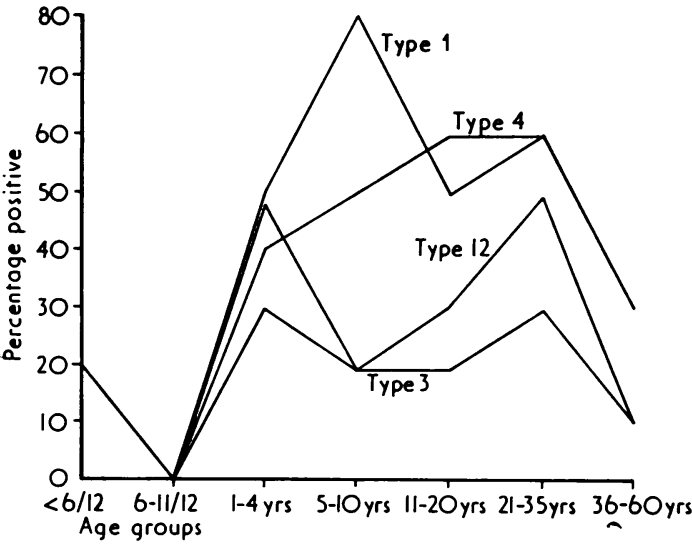

Fig $4 \operatorname{Ig} G$ ' $T$ ' antibody pattern in age group sera against adenovirus types $1,3,4$, and 12

work with rubella indicates persistence of IgM up to one year if a sensitive test is used (Pattison et al, 1975). Immunofluorescent antibody levels had a variable relation to CF levels (table I), indicating that different antibodies were measured by each technique. No advantage was seen in using immunofluorescence for serodiagnosis.

On the other hand, a survey of IgG antibodies to adenovirus types $1,2,3,5$, and 7 in age group sera showed increasing antibody geometric mean titres against types 1,2 , and 5 from birth to 4 years of age (fig 1) consistent with these viruses causing childhood infections. With adenovirus types 3 and 7 a more gradual rise was seen with higher titres in late chilhood and adult life, indicating the occurrence of such infections later in life. This type of response seen with single sera and not with paired sera from acute cases may be due to the persistence of the homotypic antibody when compared with the heterotypic antibodies. A similar survey of IgA antibody to adenovirus types 1 and 5 showed the incidence to be lower but parallel to IgG antibody. This antibody pattern probably represents residual antibody following previous infections. However, the pattern of IgM antibody against the two viruses is different; the peak at 21-35 years against type 1 is absent when tested against type 5. If this is due to the presence of antiglobulin antibodies and specific IgG antibodies giving false positives (Fraser et al, 1971), the pattern should have been similar to both agents; also the sera containing IgM antibody were negative in the latex test. IgM antibody may denote persistence of antigen in the host. So the pattern with type 1 might mean either re-infection with type 1 virus or persistence of it.

When the frequency of fluorescent IgG antibody to types 1 and 5 is compared with the neutralizing antibodies against the same two types (Potter and Shedden, 1963), a similarity is observed, some sera without adenovirus CF antibody showing the presence of fluorescent IgG. This suggests either the presence of type specific antibody in this fraction of immunoglobulins measured by IFAT or greater sensitivity of this test for group antigen than of the complement fixation test.

Measurement of adenovirus ' $T$ ' antibodies in five cases with infection showed one case with a fourfold rise, three with non rising levels, and one case with no such antibody. In acute cases and age group sera, the ' $T$ ' antibodies were detected only by staining with IgG conjugates and not with IgA or IgM conjugates. Thus fluorescent ' $T$ ' antibody may be characterized as an IgG antibody. Although subgrouping of human adenovirus types can be successfully done by measuring CF antibody to ' $T$ ' antigens, this was not the case with immunofluorescent studies, where more than one subgroup activity was seen. Although this finding is new it is not seen 
to have any diagnostic or epidemiological applications.

If serum is subjected to absorption of group specific antibody by a group antigen, it may be possible to show the presence of type specific antibody by immunofluorescence. This may lead to a valuable contribution of this method in serological epidemiology.

Our thanks are due to the World Health Organization for financial support for this research work which forms part of an M.Sc. thesis submitted to the University of Manchester, and to Dr G. E. D. Urquhart, Regional Virus Laboratory, Ruchill Hospital, Glasgow, for his interest and assistance in the preparation of this manuscript. We also wish to thank Dr M. S. Pereira, Central Public Health Laboratory, Colindale Avenue, London NW9 5HT for supplying adenovirus types 4 and 12 .

\section{References}

Bellanti, J. A., Artenstein, M. S., Brandt, B. L., Klutinis, B. S., and Buescher, E. L. (1969). Immunoglobulin responses in serum and nasal secretions after natural adenovirus infections. J. Immunol., 103, 891-898.

Cradock-Watson, J. E., Bourne, M. S., and Vandervelde, E. M. (1972). IgG, IgA and IgM responses in acute rubella determined by the immunofluorescent technique. J. Hyg. (Camb.), 70, 473-485.

De Silva, L. M., Khan, M. S., Kampfner, G., and Tobin, J. O'H. (1973). The post-mortem diagnosis of influenzal infection by fluorescent IgG, IgA and IgM antibody studies in necropsy blood. J. Hyg. (Camb.), 71, 107-112.

Feldman, L. A. and Rapp, F. (1966). Inhibition of adenovirus replication by $1-\beta$-D-arabinofuranosylcytosine. Proc. Soc. exp. Biol. (NY), 122, 243-247.

Fraser, K. B., Shirodaria, P. V. and Stanford, C. F. (1971). Fluorescent staining and human IgM. (Letter.) Brit. med. J., 3, 707.

Gilden, R. V., Kern, J., Lee, Y. K., Rapp, F., Melnick, J. L., Riggs, J. L., Lennette, E. H., Zbar, B., Rapp, H. J., Turner, H. C., and Huebner, R. J. (1970). Serologic surveys of human cancer patients for antibody to adenovirus 'T' antigens. Amer. J. Epidem., 91, 500-509.

Ginsberg, H. S. (1972). Adenoviruses. Amer. J. clin. Path., 57, 771-776.

Huebner, R. J., Rowe, W. P., and Lane, W. T. (1962) Oncogenic effects in hamsters of human adenovirus types 12 and 18. Proc. nat. Acad. Sci. (Wash.), 48, 2051-2058.

Pattison, J. R., Dane, D. S., and Mace, J. E. (1975). Per- O sistence of specific IgM after natural infection with rubella virus. Lancet, 1, 185-187.

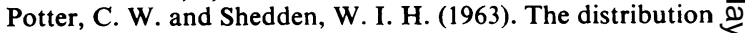
of adenovirus antibodies in normal children. J. Hyg. (Camb.), 61, 155-160.

Rosen, L. (1960). A haemagglutination-inhibition technique for typing adenoviruses. Amer. J. Hyg., 71, 120-122.

Trentin, J. J., Yabe, Y., and Taylor, G. (1962). The quest for human cancer viruses. Science, 137, 835-841.

Urquhart, G. E. D. (1974). Serum IgM and IgA responses in influenza A infections. J. clin. Path., 27, 198-201. 